\title{
Black Travesty
}

Angela Khristin Brown
2815 South Buffalo Drive
Las Vegas, NV 89117
E-mail: brownlas6@aol.com

Doi:10.7575/aiac.alls.v.4n.1p.145

URL: http://dx.doi.org/10.7575/aiac.alls.v.4n.1p.145
Received: 01/12/2012

Accepted: 03/01/2013

Quincy Troupe is a visionary poet who is always reaching out to walk and dance words upon a single page. Quincy uses his imagination through dialog with certain looks of rhythm of words which bounce off the page of unforgotton sound. Quincy prances accross word that burst from childhood dreams that make you smile. Perhaps there is an explanation to why he creates hope to the deturbed voices in our head. It is through language that he decodes similes, metaphores and apostrophes out of clarity that trace our roots to our dark past which is from the eye of the beholder. Quincy's words bounce back at us with words of wisdom from the voice that humms in our head. Quincy maps his experience into beautiful shcemes of imprisoned thought. Quincy has mirrored a managerie of space on a blank page using pain and agony to slowly develop an illusion for movement. Quincy's sentex is the blues in space that echoes in the air in spoken tongues. It is from dreams we pulsate life through shared idioms of time. When we can identify in how sorrow has touched our lives, we believe in fear itself will keep us alive. Fear is an invisible ploom we live through rituals from desire. It is from this madness we imagine love is far deeper than fear itself.

Young Blood Interpretation, By Angela Khristin Brown

Under the weather. The one true love. It is bitter hot. Hot wind can burn. The taste of sweat, sizzles. A fresh blow of air. The angry wind blows hot air. I anticipate the tension of gas transpire. Can you survive the heat? I can. My body is amund to the conditions. Only resistance could bring it to tolerate the pain. I live in an surreal world. My world is imaginary. Images from my mind control my fate. I have the will to make the future come as I dream it. Of my life. At night, as I sleep, I see things that come true. If I am scared of dying, it is my fate. Some call it witch craft. If I were afraid someone will die in my dream, that person dies. Having the ability to see the future is witch craft. Only god controls destiny. The one who I felt was the one to marry. Time holds disposition to hover memories. Man follies with desire to hoard feelings we don't want to understand. Mere inequity. The man did not feel the same as I did for him. Faltering mistakes. Bitterness weather. Man bids his last request to reconcile notions. Experience unresolved. A body thirst for solvency. Salt, a ubiquities cry for mercy. Insomnia, a reflection to homelessness. My true love was my first love. Dismantled bodies spirits travel as ghosts. Crying. Crying an morbid pain. An uncertainty to reason thoughts. I had never known what love meant until I met him. The wind howls. The wind cries for mercy. Pain from the deceived that howls for freedom. And now he is gone and will never return. An addiction to seek wisdom. Retaliation from desire to sustain probability. Question action for meaning. Our love was never meant to be. Statements used to entertain from fault to remain present. Unwelcome solitude unforgiving. The mind has its limits. Weathers revenge is a minds deadly defeat. Immortal death. To live life without reason. To be disillusioned about reincarnation. Life is a continuum of immortal dreams. It is better to love and lost. It is to imprison your soul within. Life has no mercy. Than it is to not ever have felt love at all. Where there are no real solutions to live by. Only a quest to live immortally, knowing that your dreams will live for eternity. One must learn love from experiences....John Oliver Killens

\section{Blues, By Angela Khristin Brown}

Those five or six young guys

lunched on the stoop

that oven-hot summer night

whistled me over. Nice

and friendly. So, I stop.

MacDougal or Christopher

Street in chains of light.

A summer festival. Or some

saint's. I wasn't too far from

home, but not too bright

for a nigger, and not too dark.

I figured we were all

one, wop, nigger, jew, 
besides, this wasn't Central Park.

I'm coming on too strong? You figure

right! They beat this yellow nigger

black and blue.

Yeah. During all this, scared

on case one used a knife,

I hung my olive-green, just-bought

sports coat on a fire plug.

I did nothing. They fought

each other, really. Life

gives them a few kcks,

that's all. The spades, the spicks.

My face smashed in, my bloddy mug

pouring, my olive-branch jacket saved

from cuts and tears,

I crawled four flights upstairs.

Sprawled in the gutter, I

remember a few watchers waved

loudly, and one kid's mother shouting

like 'Jackie' or 'Terry,'

'now that's enough!'

It's nothing really.

They don't get enough love.

You know they wouldn't kill

you. Just playing rough,

like young Americans will.

Still it taught me somthing

about love. If it's so tough,

forget it.

Derek Walcott poetry is a glimpse of how we review our journey. His writing is " a theatre of the sea." Derek presence is untouched. Derek's poetry is a window of hope. Derek has created an awareness that perpetuate a purpose amongst us which is a pencil that sketched a blue print in art. Derek draws an arguement of betrayal in how artifacts become affectious words. One can sence the moral pride of infectious meaning that commences in his poem. The words in Derek's poems encourages us to to imagine a moral conformity, mystical to truth. Derek uses a delusion of a contorted experience that melts our heart. The words of Derek's poems becomes a device for rituals used to induce time. With Derek, darkness becomes sunrise. Words become spiritual essential to the artform. Nature is a pastoral place of response used in couplets, quartrains and blank verse. We must never forget his message that thunders an empty space within a perimeter of matter. Words are used as a structure pondering ideas of emotions that should not be disalusioned in society. With Derek, the idea of reconciliation becomes a metaphore for purpose. Sometimes when he feel pain, there is an urgency to trust your heart to the ones who really love you.

Negratude Verse: Written by, Angela Khristin Brown

Maryse Condé is a fellow American who has voiced her vision on American culture with great confidence. Maryse involvement with the black community has voiced the truth about human condition in America. Maryse has encouraged a struggle of competence to negotiating peace amongst races. Maryse is a prospect for peace. Maryse has negotiated amongst her peers words of wisdom to unity to ignite immediate insight to the ailing problem that devides our nation. Maryse is like a friend of circumstance we welcomed with the urgency we have come to recognize. Maryse has been a voice of a generation of freedom. Let us understand the essence of her presence in our lives to impose value to understand our own faults to emplify transition. Maryse is an amazing woman. She has lead us to believe in our race, our struggles as a race who has aspireed our race the reasons why we live, the reasons for our struggle, our plight to choice. Maryse poems are about what our race is facing today. Her work is a call of reflection to mediate answers. A call for change. We must not withdraw our cause for peace or we will be a slave hobbiting terror of a self-inflicting wound. Maryse has managed to speek comfort in our leadership as a nation as a voice understood accross cultures. Maryse has a voice in our conquest to be heard as victims of rejection. Rejection can destroy our commitment. Maryse encourages change. Change is a result of acceptance. It is what holds our future. There is a need for Mayrse to disclose purpose and humiliation in her work. Poetry is the intiative of explored thought. It is through words that mediate ideas. In Maryse poems, extends all hope and all justice. In addition, Maryse communicates with her audience progress. Maryse is a mediator of words of conviction. Maryse is an element of inspiration who teaches the conviction that we are responsible for our own actions. Maryse is a council of American convention of human spirit that has met many challenges. It is from these challenges, which must be redeemed. Maryse work is an advocator who demands attention, 
with deep concern from individuals who care to listen. It is from Maryse voice which brings justice to us all.

Discerning Language, By Angela Khristin Brown

When you deal with a person who's experiencing dementia, you can see where they're struggling with knowledge. You can see what they forget completely, what they forget but they know what they once knew. You can tell how they're trying to remember. Walter Mosley

Walter Mosley influences our lives differently in how we identify and evaluate who we are as individuals. We respond to life situations in how we interpret ourselves. How we function in society as a whole, signifies invaluable differences in how we base our demeanor.

Mosley poems are defined by the image you make of yourself and not what others lead you to believe. It is how you read his poems that convey your self-image. Mosley's poetry is only a measurement. From memories since a child, I encounter times where I question my beauty. As I grew older, I began to understand the nature behind being beautiful meant to me. There are several journeys that led me to this altercation, which were grief, love and loneliness. All of these matters, because of the pain I faced made me a better person. I can identify with self-hate through attempting suicide. Self-pity is a form of grief. It takes a lot of energy to feel lonely because you hate what you do not understand. Self-pity comes from wanting to accept love in your life, when you do not understand the best love is from those who mean it.

Mosley poems is an image. An image becomes a menagerie for acceptance. Mosley's poems can identify with what it means to love yourself. One must find true happiness, in order to love oneself and this will be reached after full maturation. The feeling of grief, love and loneliness is defined by reason. Mosely's poems determines character. By reading Mosely's poems is how we react to what motivates our actions. Our actions justify our fate. We are accountable our actions through interpretation in what dictates an experience or desire to promote change. Mosely poems is a reflection of our ability to transform into the imagery of the poems.

Walter Mosley is a choice poet. Mosely poems is a since of existence. Mosley language speaks of honesty, idealism and filters emotions we can all relate to. Mosley speaks from life experience of his inner child. His poems are reflective of idealism. Mosely has a gift of transending words into metaphores. A good work ethic is a passable poem which implicate reason. It is how to articulate words in speech that make Mosely words a powerful form. Mosely conveys meaning through his work. One must read between the lines of a poem to become convinced in Mosely artistry. It is from the language in words that convey meaning.

\section{Passing Love, By Angela Khristin Brown}

on the Civil Rights Struggle

there is not a day that goes by neglected

nor a moment left to spare

there is not a time hope is mistaken

nor a minuit death cries in dispair

and when the stars shine above heaven

and the rain covers in a deadly mask

it is fear that controls your destiny

while emptiness explores the past

there is not a day I ask God for forgiveness

nor a time my thoughts left confused

there is not a time I feel unrejected

nor a moment I flea the abuse

it is silence that counts in silence

there is work that makes up what to be done

the free is not free from uncertainty

the mind is an aspiration of one 
you can control your life,

or let your life control you

keep an open mind,

you are free when it is meant to be

life is amazing 